\title{
SPONTANEOUSLY PRECIPITATED BENCE JONES PROTEIN IN URINE *
}

\author{
JACOB ROSENBLOOM, M.D. \\ NEW YORK
}

In another paper ${ }^{1} \mathrm{I}$ have reviewed the various theories which have been proposed regarding the origin of Bence Jones protein. In the paper preceding this one $I$ have described experiments which, conducted under the direction of Prof. W. J. Gies, were planned to determine whether osseo-albumoid, a constituent of bone, is a precursor of Bence Jones protein. That inquiry warranted the conclusion that the Bence Jones protein may be formed from osseo-albumoid by the action of enzymes in diseased bone.

The chemical nature of Bence Jones protein has been thoroughly studied, but very little is known regarding the mode of formation of this important substance. Weber and Ledgingham ${ }^{2}$ have suggested that the cytoplasmic residue of karyolyzed plasma cells is the source of Bence Jones protein. If this view is correct, the endogenous purins of the urine should be supernormal in amount owing to increased nuclear destruction. Preparations were made for a thorough inquiry into this particular phase of the subject through study of the urine of a patient with multiple myeloma. The patient died, however, before the work was well under way. Considerable Bence Jones protein was available, nevertheless, and a number of facts of chemical interest, which were noted, are mentioned below.

\section{General Description of the Urine}

The twenty-four hour urine was examined daily for a period of eight days. During this period it was noticed that with but one exception, about one-third the bulk of each specimen was occupied by a pinkish

* The clinical history and findings of this case were those of multiple myeloma. The writer wishes to thank Dr. Davison, under whose service at Mt. Sinai Hospital the patient was observed. It is also a pleasure to acknowledge the hearty cooperation obtained from Drs. Bookman, Crohn, Mandlebaum and Munker.

* From the Laboratory of Biological Chemistry of Columbia University, at the College of Physicians and Surgeons, and the Chemical Department of Mt. Sinai Hospital, New York City.

1. Rosenbloom: Biochem. Bull., 1911, i, 161.

2. Weber and Ledgingham: Proc. Roy. Soc. Med., Path. Sect., 1909, ii, 193; Folia hematol., 1909, viii, 14. 
sediment, which, after removal by filtration, was found to give all the reactions typical of Bence Jones protein. ${ }^{3}$

The volumes of the daily urines varied between 1,200 c.c. and 1,450 c.c. On heating the filtered urine a precipitate was produced at from 50 to $51 \mathrm{C}$. The precipitate increased in bulk on heating to $55 \mathrm{C}$. At $56 \mathrm{C}$. the precipitate flocculated in a clear surrounding liquid. At $78 \mathrm{C}$, solution of the precipitate began. At $90 \mathrm{C}$., complete solution of the precipitate occurred. As the heated urine cooled, the precipitate reappeared.

Such clear-cut heat-precipitation was not always obtainable at the temperatures indicated. In some of the urine the precipitate would not completely dissolve at the highest temperatures. The temperature of initial coagulation also varied. The first signs of turbidity were always obtained at a temperature between 51 and $55 \mathrm{C}$., and solution of the precipitate began at a temperature between 78 and $81 \mathrm{C}$.

When the urines were made alkaline with sodium hydroxid, heat failed to induce precipitation, but after acidification of such alkalized urine, heat-precipitation could be elicited.

Nitric acid solution (25 per cent.), when added in small quantity to the fresh urine, caused cloudiness. On shaking the mixture the turbidity disappeared. The addition of a chemical excess of the acid produced an abundant precipitate. When the acid mixture was heated the precipitate dissolved. This precipitate was insoluble in a physical excess of the acid. Hydrochloric and sulphuric acids gave the same reaction. Picric, tannic, phosphotungstic, sulphosalicylic and metaphosphoric acids produced precipitates but the corresponding precipitates did not dissolve completely when the mixtures were heated. The addition of two volumes of alcohol to the urine caused complete precipitation of the reactive substance. This precipitate was soluble in water but, when immersed in alcohol for a week, it became insoluble in water.

Saturation of the urine with sodium chlorid failed to effect precipitation but, on heating this saturated solution, an abundant precipitate was produced. The precipitate did not dissolve on further heating. Saturation of the urine with magnesium sulphate, after making the urine acid, caused heavy precipitation. This precipitate did not dissolve when the mixture was boiled. On saturating the neutralized urine with ammonium sulphate, and also on saturating the acid urine with sodium sulphate, complete precipitation of protein occurred.

Serum protein was absent from the urine of this patient during the period of observation. The amount of the heat-precipitable protein which

3. Bradshaw (Trans. Med-Chir. Soc., Lond., 1898, lxxxi, 259; Brit. Med. Jour., 1898, $i, 1136$ ) has described a similar case in which the substance was spontaneously precipitated. Williams (Biochem. Jour., 1910, v. 225) described urine containing Bence Jones protein, and stated that on several occasions the urine was milky when voided. He did not say whether the milkiness was due to Bence Jones protein. 
was excreted in twenty-four hours varied from 3 to $5 \mathrm{gm}$. It contained from 8 to 15 per cent. of the total nitrogen.

\section{Chemical Data on the Substance Isolated from the Urine}

The purified, heat-precipitable protein was obtained from the urine by the following method: T'he urine was heated slowly to $60 \mathrm{C}$. and the precipitate filtered off. (This coagulation was so complete that the filtrate gave no protein reactions.) The precipitate was washed with cold water, dissolved by means of 0.5 per cent. sodium carbonate solution and precipitated from this solution by alcohol. The precipitate was dialyzed in running water for a week, then washed with absolute alcohol and ether, and dried at $105 \mathrm{C}$. The substance prepared by this method had, the general appearance of dry egg-albumin. It was insoluble in water but dissolved in dilute alkali.

The nitrogen content of this material varied between 15.08 per cent. and 15.24 per cent. The sulphur content varied between 1.12 per cent. and 1.25 per cent. Phosphorus was absent. The purified material responded to the following tests: Millon, Liebermann, biuret, xanthroproteic, Adamkiewicz, and Molisch. In peptic digestion it yielded protoproteose, secondary proteoses, and peptone, but no heteroproteose. A solution of the purified substance in 0.5 per cent. sodium carbonate did not give the heat-precipitation test, but on the addition of sufficient saline material and acid, this test could be obtained.

These facts make it evident that the material under investigation was true Bence Jones protein. 